\title{
Factors associated with early weaning at a Child-Friendly Healthcare Initiative Hospital
}

\author{
Fatores associados ao desmame precoce em \\ Hospital Amigo da Criança
}

\begin{abstract}
Purpose: Considering the benefits of breastfeeding on children's health, the aim of the present study was to determine factors associated with early weaning among children at a ChildFriendly Healthcare Initiative (CFHI) children's hospital in the city of Campina Grande, state of Paraíba, Brazil.

Methods: An analytical, cross-sectional study was carried out involving 800 mothers of children between 0 and 24 months of age at the Elpídio de Almeida Health Institute. A semi-structured questionnaire was administered and contained questions on socio-demographic characteristics, eating habits and nonnutritive sucking habits. The chi-square test and Fisher's exact test were employed for statistical analysis. A multivariate analysis was performed with variables that achieved a $P$-value $<0.25$ in the bivariate analysis.

Results: The prevalence of early weaning was $13.5 \%$. In the bivariate analysis, the factors associated with early weaning were income $(P=0.001)$, child's birth weight $(P=0.016)$, bottle feeding $(P=0.003)$ and pacifier use $(P<0.001)$. In the multivariate analysis, pacifier use remained significantly associated with early weaning (OR: $3.23 ; 95 \% \mathrm{Cl}: 1.871$ to 5.591 ; $P<0.001)$.
\end{abstract}

Conclusion: Pacifier use was associated with early weaning, even when mothers were advised to avoid this habit.

Key words: Breastfeeding; risk factors; early weaning

\section{Resumo}

Objetivo: Considerando os benefícios da amamentação para a saúde da criança, o objetivo do presente estudo foi determinar os fatores associados com o desmame precoce entre as crianças em um Hospital Amigo da Criança na cidade de Campina Grande, estado da Paraíba, Brasil. Metodologia: Um estudo analítico e transversal foi realizado com 800 mães de crianças entre 0 e 24 meses de idade, no Elpídio de Almeida Instituto de Saúde. Um questionário semi-estruturado foi aplicado, contendo perguntas sobre características sócio-demográficas, hábitos alimentares e hábitos de sucção não nutritiva. $\bigcirc$ teste do qui-quadrado e teste exato de Fisher foram empregados na análise estatística. A análise multivariada foi realizada com as variáveis tendo atingido um valor de $P<0,25$ na análise bivariada.

Resultados: A prevalência de desmame precoce foi de 13,5\%. Na análise bivariada, os fatores associados com o desmame precoce foram: renda $(P=0,001)$, peso de nascimento da criança $(P=0,016)$, uso de mamadeira $(P=0,003)$ e uso de chupeta $(P<0,001)$. Na análise multivariada, $\mathrm{O}$ uso de chupeta permaneceu significativamente associada com o desmame precoce (OR: 3,23 IC 95\%: 1,871-5,591, $P<0,001$ ).

Conclusão: $O$ uso de chupeta foi associado com o desmame precoce, mesmo quando as mães foram aconselhadas a evitar esse hábito.

Palavras-chaves: Amamentação; fatores de risco; desmame precoce

\author{
Ana F. Granville-Garcia a \\ Ruthinéia D.A.U. Lins a \\ Ana C.B. Oliveira ${ }^{b}$ \\ Saul M. Paiva ${ }^{b}$ \\ Raulison V. Sousa a \\ Veruska Martins a \\ Maria S. P. Silva a \\ Jainara M.S. Ferreira ${ }^{c}$ \\ Valdenice A. Menezes d
}

\begin{abstract}
a Postgraduate Program in Dentistry, State University of Paraiba, Campina Grande, PB, Brazil

b Postgraduate Program in Dentistry, Federal University of Minas Gerais, Belo Horizonte, MG, Brazil

c Dental School, University Center of João Pessoa (UNIPÊ), João Pessoa, PB, Brazil

d Postgraduate Program in Dentistry, State University of Pernambuco, Recife, PE, Brazil
\end{abstract}

Correspondence:

Ana Flávia Granville-Garcia

Rua Cap. João Alves Lira 1325/410, Bela Vista

Campina Grande, PB - Brasil

58101-281

E-mail: anaflaviagg@hotmail.com

Received: February 18, 2012

Accepted: August 8, 2012

Conflict of Interests: The authors state that there are no financial and personal conflicts of interest that could have inappropriately influenced their work.

Copyright: (C) 2012 Granville-Garcia et al.; licensee EDIPUCRS. This is an Open Access article distributed under the terms of the Creative Commons AttributionNoncommercial-No Derivative Works 3.0 Unported License. 


\section{Introduction}

A public health policy in Brazil that addresses the advantages of breastfeeding has been considered to be one of the fundamental pillars for the promotion, protection and support of nursing mothers and infants (1). Mother's milk has nutritional and immunological properties that play a role in the recovery from illness and the reduction in child mortality rates. The act of breastfeeding also favors the cognitive development of the child (2), avoids the development of mouth-breathing syndrome, and promotes the correct establishment of stomatognathic functions.

The literature reports that early weaning from breastfeeding may disrupt oral motor development, impairing the functions of chewing, swallowing, breathing and the articulation of sounds of speech and can lead to the development of malocclusion (3,4-6). In Brazil, the following prevalence rates of early weaning have been reported: $16.1 \%$ in Rio Branco (7), 27.3\% in Alagoas (5), $29.9 \%$ in Maringá (8), 41.4\% in Bezerros (9) and 63.3\% in Campinas (1). The cessation of breastfeeding before six months of age may be related to cultural and social factors $(8,10,11)$.

The prevalence of breastfeeding through the age of six months has increased in Brazil from 49\% in the 1980s to $60 \%$ in the $1990 \mathrm{~s}$ (12). However, this increase in the breastfeeding rate has not been homogeneous across the country, as significant variations are seen, depending on the region and socioeconomic characteristics of the population studied (1). Thus, early weaning remains a public health problem in the country (13).

As a strategy to encourage breastfeeding, the WHO and the United Nations Children's Fund (UNICEF) proposed the Child-Friendly Healthcare Initiative (CFHI), which aims to encourage institutions, health professionals and the community to make conscious choices regarding the proper feeding of children in early life (14).

The aim of the present study was to identify factors associated with early weaning at a CFHI hospital in the city of Campina Grande, state of Paraíba, Brazil, and to offer data that can contribute to the planning of public health policies directed at the promotion of breastfeeding.

\section{Methodology}

This study received approval from the Human Research Ethics Committee of the Universidade Estadual da Paraíba (Brazil) under process number 0192.0.133.000-08, in compliance with Resolution 196/96 of the Brazilian National Health Council. All interviewed mothers agreed to participate by signing a statement of informed consent.

An analytical, cross-sectional study was carried out for the evaluation of variables related to socio-demographic characteristics, dietary patterns and nonnutritive sucking habits among children of mothers discharged from the
Elpidio de Almeida Health Institute, which is CFHI member, in the city of Campina Grande, state of Paraíba, Brazil. Three hospitals in this city have CFHI status. The Elpidio de Almeida Health Institute is the largest, and it is considered a point of reference in the city and surrounding areas; it was therefore selected as the location for the present study.

The inclusion criteria were mothers whose children (less than two years of age) were treated at the Elpidio de Almeida Health Institute and who signed a statement of informed consent. The exclusion criteria were mothers that were prevented from breastfeeding due to health problems, those with drug addictions, those who had used drugs during lactation, those who refused to participate and those whose infants presented problems that prevented or hindered breastfeeding.

The sample size was calculated from an estimation of annual care $(n=4800)$, based on the monthly care estimates of the institute ( 400 patients per month). Considering a $5 \%$ maximal acceptable error and a 99\% confidence level, a minimum acceptable sample of 584 mothers was determined using the Epi Info ${ }^{\mathrm{TM}} 6$ program. To compensate for possible losses, the sample was increased to 800 mothers.

Through an interview using a structured questionnaire, the mothers were asked about the feeding patterns of their infants during the period from October 2008 to February 2009. The reliability of the responses was tested using the "face" validation method in $10 \%$ of the respondents. With this method, the researcher investigates the understanding of each question by asking the respondent to rephrase with question in her own words (15). Early weaning was defined as the complete interruption of breastfeeding in the first six months of life (1).

Data analysis involved the chi-square test and Fisher's exact test (5\% level of significance), using the Statistical Package for the Social Sciences (SPSS v.13.0). A multivariate logistic regression analysis was performed with all variables that achieved a $P$-value $<0.25$ in the bivariate analysis.

\section{Results}

The prevalence of early weaning was $13.5 \%(\mathrm{n}=108)$. Table 1 displays the socio-demographic characteristics of the mothers that reported early weaning. Table 2 displays the characteristics and nonnutritive sucking habits of the children that exhibited early weaning. According to the bivariate analysis, the following factors were associated with early weaning: family income $(P=0.001)$, birth weight of the child $(P=0.016)$, bottle feeding $(P=0.003)$ and pacifier use $(P<0.001)$.

Table 3 displays the results of the multiple logistic regression. Only three variables remained in the final model (family income, bottle feeding and pacifier use), with pacifier use alone proving to be significantly associated with early weaning $(P<0.001)$. 
Table 1. Evaluation of early weaning according to mothers' socio-demographic characteristics; Campina Grande, Paraíba, Brazil

\begin{tabular}{|c|c|c|c|c|c|c|c|c|}
\hline \multirow{3}{*}{ Variable } & \multicolumn{4}{|c|}{ Early weaning } & \multirow{2}{*}{\multicolumn{2}{|c|}{ TOTAL }} & \multirow{3}{*}{$P$-value } & \multirow{3}{*}{ OR $(95 \% \mathrm{Cl})$} \\
\hline & \multicolumn{2}{|c|}{ Yes } & \multicolumn{2}{|c|}{ No } & & & & \\
\hline & $\mathrm{N}$ & $\%$ & $\mathrm{~N}$ & $\%$ & $\mathrm{~N}$ & $\%$ & & \\
\hline \multicolumn{9}{|l|}{ Age group } \\
\hline $14-20$ years & 30 & $13.5 \%$ & 193 & $86.5 \%$ & 223 & $100 \%$ & \multirow{2}{*}{$0.981^{(1)}$} & \multirow{2}{*}{$0.994(0.632-1.564)$} \\
\hline 21 years or more & 78 & $13.5 \%$ & 499 & $86.5 \%$ & 577 & $100 \%$ & & \\
\hline \multicolumn{9}{|l|}{ Marital status ${ }^{* *}$} \\
\hline Single & 25 & $13.1 \%$ & 166 & $86.9 \%$ & 191 & $100 \%$ & \multirow{2}{*}{$0.837^{(1)}$} & \multirow{2}{*}{$0.951(0.588-1.537)$} \\
\hline Married & 83 & $13.7 \%$ & 524 & $86.3 \%$ & 607 & $100 \%$ & & \\
\hline \multicolumn{9}{|l|}{ Schooling } \\
\hline$<8$ years & 90 & $14 \%$ & 553 & $86 \%$ & 643 & $100 \%$ & \multirow{2}{*}{$0.405^{(1)}$} & \multirow{2}{*}{$1.257(0.733-2.155)$} \\
\hline 8 years or more & 18 & $11.5 \%$ & 139 & $88.5 \%$ & 157 & $100 \%$ & & \\
\hline \multicolumn{9}{|l|}{ Works outside home** } \\
\hline Yes & 20 & $12.9 \%$ & 135 & $87.1 \%$ & 155 & $100 \%$ & \multirow{2}{*}{$0.803^{(1)}$} & \multirow{2}{*}{$0.936(0.556-1.575)$} \\
\hline No & 88 & $13.7 \%$ & 556 & $86.3 \%$ & 644 & $100 \%$ & & \\
\hline \multicolumn{9}{|l|}{ Household Income } \\
\hline 3 or + times the minimum salary & 21 & $26.3 \%$ & 59 & $73.8 \%$ & 80 & $100 \%$ & \multirow{2}{*}{$0.000 *(1)$} & \multirow{3}{*}{$2.590(1.50-4.471)$} \\
\hline$\leq 2$ times the minimum salary & 87 & $12.1 \%$ & 633 & $87.9 \%$ & 720 & $100 \%$ & & \\
\hline Total group & 108 & 13.5 & 692 & 86.5 & 800 & & & \\
\hline
\end{tabular}

* Significant difference at 5.0\%; ** Some interviewees did not provide this information.

(1) Chi-square test.

Table 2. Evaluation of early weaning according to pregnancy characteristics and nonnutritive sucking habits of children; Campina Grande, Paraíba, Brazil

\begin{tabular}{|c|c|c|c|c|c|c|c|c|}
\hline \multirow{3}{*}{ Variable } & \multicolumn{4}{|c|}{ Early weaning } & \multirow{2}{*}{\multicolumn{2}{|c|}{ TOTAL }} & \multirow{3}{*}{$P$-value } & \multirow{3}{*}{ OR $(95 \% \mathrm{Cl})$} \\
\hline & \multicolumn{2}{|c|}{ Yes } & \multicolumn{2}{|c|}{ No } & & & & \\
\hline & $\mathrm{N}$ & $\%$ & $\mathrm{~N}$ & $\%$ & $\mathrm{~N}$ & $\%$ & & \\
\hline \multicolumn{9}{|l|}{ Gender } \\
\hline Male & 61 & $14.2 \%$ & 368 & $85.8 \%$ & 429 & $100 \%$ & \multirow{2}{*}{$0.522^{(1)}$} & \multirow{2}{*}{$1.14(0.75-1.72)$} \\
\hline Female & 47 & $12.7 \%$ & 324 & $87.3 \%$ & 371 & $100 \%$ & & \\
\hline \multicolumn{9}{|l|}{ Birth weight $(\mathrm{g})^{* *}$} \\
\hline$<2.5 \mathrm{~kg}$ & 16 & $21.9 \%$ & 57 & 78.1 & 73 & $100 \%$ & \multirow{2}{*}{$0.016 *(1)$} & \multirow{2}{*}{$2.065(1.134-3.761)$} \\
\hline $2.5 \mathrm{~kg}$ or + & 84 & $12 \%$ & 618 & $88 \%$ & 702 & $100 \%$ & & \\
\hline \multicolumn{9}{|l|}{ First child } \\
\hline Yes & 60 & $15.3 \%$ & 333 & $84.7 \%$ & 393 & $100 \%$ & \multirow{2}{*}{$0.151^{(1)}$} & \multirow{2}{*}{$1.348(0.896-2.026)$} \\
\hline No & 48 & $11.8 \%$ & 359 & $88.2 \%$ & 407 & $100 \%$ & & \\
\hline \multicolumn{9}{|l|}{ Planned pregnancy } \\
\hline Yes & 56 & $12.8 \%$ & $383 \%$ & $87.2 \%$ & 439 & $100 \%$ & \multirow{2}{*}{$0.497^{(1)}$} & \multirow{2}{*}{$0.869(0.579-1.304)$} \\
\hline No & 52 & $14.4 \%$ & $309 \%$ & $85.6 \%$ & 361 & $100 \%$ & & \\
\hline \multicolumn{9}{|l|}{ Prenatal } \\
\hline Yes & 107 & $13.5 \%$ & 687 & 86.5 & 794 & $100 \%$ & \multirow{2}{*}{$0.582^{(2)}$} & \multirow{2}{*}{$0.779(0.090-6.730)$} \\
\hline No & 1 & $16.7 \%$ & 53 & 83.3 & 6 & $100 \%$ & & \\
\hline \multicolumn{9}{|l|}{ Type of delivery } \\
\hline Normal & 61 & $13.7 \%$ & 682 & $86.3 \%$ & 790 & $100 \%$ & \multirow{2}{*}{$0.374^{(2)}$} & \multirow{2}{*}{$0.863(0.840-0.888)$} \\
\hline Cesarean & - & - & 10 & $100 \%$ & 10 & $100 \%$ & & \\
\hline \multicolumn{9}{|l|}{ Pacifier sucking } \\
\hline Yes & 83 & $27.3 \%$ & 221 & $72.7 \%$ & 304 & $100 \%$ & \multirow{2}{*}{$<0.001^{*(1)}$} & \multirow{2}{*}{$7.076(4.401-11.376)$} \\
\hline No & 25 & $5 \%$ & 471 & $95 \%$ & 496 & $100 \%$ & & \\
\hline \multicolumn{9}{|l|}{ Bottle feeding** } \\
\hline Yes & 107 & $37.4 \%$ & 179 & $62.6 \%$ & 286 & $100 \%$ & \multirow{2}{*}{$0.003^{*(2)}$} & \multirow{2}{*}{$10.760(1.416-81.751)$} \\
\hline No & 1 & $5.3 \%$ & 18 & $94.7 \%$ & 19 & $100 \%$ & & \\
\hline Total Group & 108 & 13.5 & 692 & 86.5 & 800 & 100.0 & & \\
\hline
\end{tabular}

* Significant difference at $5.0 \%$; ** Some interviewees did not provide this information.

(1) Chi-square test; (2) Fisher's exact test. 
Table 3. Logistic regression results for early weaning; Campina Grande, Paraíba, Brazil

\begin{tabular}{|c|c|c|c|}
\hline \multirow{2}{*}{ Variable } & \multicolumn{2}{|c|}{ OR and $95 \% \mathrm{Cl}$} & \multirow{2}{*}{$P$-value } \\
\hline & Bivariate analysis & Adjusted model & \\
\hline \multicolumn{4}{|l|}{ Family income } \\
\hline 3 or + times the minimum salary & 2.590 (1.5 to 4.471$)$ & 1.307 (0.945 to 1.807$)$ & 0.106 \\
\hline \multicolumn{4}{|l|}{$\leq 2$ times the minimum salary } \\
\hline \multicolumn{4}{|l|}{ Bottle feeding } \\
\hline Yes & 10.760 (1.416 to 81.751$)$ & 5.498 (0.697 to 43.362$)$ & 0.106 \\
\hline \multicolumn{4}{|l|}{ No } \\
\hline \multicolumn{4}{|l|}{ Pacifier sucking } \\
\hline Yes & 7.076 (4.401 to 11.376$)$ & $3.234(1.871$ to 5.591$)$ & $<0.001^{*}$ \\
\hline No & & & \\
\hline
\end{tabular}

(*) Significant difference at 5.0\%.

\section{Discussion}

In the present study, $13.5 \%$ of the children were weaned early, which is a lower percentage than those reported in other Brazilian studies $(1,5,7,9)$. This low percentage may be a consequence of the efforts of the Elpidio de Almeida Health Institute to prevent early weaning. The institution follows the ten steps for successful breastfeeding, which include the education of the mother regarding the benefits of exclusive breastfeeding, awareness on the part of the health team regarding the importance of breastfeeding, recommendations for the non-use of bottles and pacifiers on the hospital grounds and the encouragement of mothers to avoid these practices following discharge from the hospital (14). Other studies have evaluated the impact and importance of such programs in promoting breastfeeding $(16,17)$.

In the present study, the mother's age exerted no influence on the discontinuation of breastfeeding (Table 1), which is in agreement with findings described in the literature $(1,8,9)$.

Studies report that greater marital stability or the presence of a partner provides a positive influence in extending the breastfeeding period (8). However, the analysis of the participants' marital status revealed no significant association with the occurrence of early weaning (Table 1). Similar findings have also been described by other authors (1).

Although studies indicate that the mother's education is related to early weaning $(1,8,16,18,19)$, no significant association was found between these variables in the present study (Table 1). Moreover, no significant association was found between working outside the home and early weaning (Table 1), which is in agreement with findings reported in previous studies $(9,16)$. However, some studies report that working outside the home is a factor that hinders the establishment of adequate breastfeeding $(20,21)$.

A significant association was found between a higher household income and early weaning. Families with a monthly income equal to or greater than three times the Brazilian minimum salary (U\$ 320) had a higher risk of early weaning (Table 1), a result that differs from data reported in the literature $(9,22)$. This finding may be explained by the easier access to breast milk substitutes for this portion of the population.

A number of studies report the influence of gestational characteristics on early weaning, such as primiparity, unwanted pregnancy and the completion of prenatal care $(1,9)$. However, this association was not found in the present study (Table 2). Likewise, no association was found between the child's gender and early weaning (Table 2), which is in agreement with findings reported in the literature (18). Birth weight can interfere with the breastfeeding practice, and it is a determinant of child survival and neonatal nutritional planning $(3,14)$. The bivariate analysis revealed an association between low birth weight and early weaning (Table 2). However, this variable lost its significance following the adjustment of the model. These results are in agreement with findings described in the literature (19).

As in this study (Table 2), a number of authors have reported the influence of pacifier use and/or bottle feeding on early weaning $(1,8-10,19,23)$. However, multivariate analysis indicated that only the habit of pacifier sucking was significantly associated with early weaning (Table 3 ). The introduction of a pacifier or bottle, especially at the beginning of the breastfeeding period, seems to confuse the sucking reflex through the "nipple confusion" phenomenon, which determines the incorrect positioning of the infant's tongue when suckling at the breast and leads to early weaning (24). Moreover, women who introduce pacifiers tend to breastfeed their infants less frequently and experience breastfeeding problems that are consistent with infrequent feeding, thereby contributing to early weaning (25). In this sense, the CFHI contributes to child health policies in Brazil through the support of breastfeeding with the aim of improving the quality of life of Brazilian children.

Although the prevalence of early weaning reported in the present study may be relatively low, the factors associated with this practice are similar to those reported in previous studies in populations served by institutions not accredited by the CFHI $(9,19)$. This underscores the importance of 
strategies aimed at encouraging the practice of exclusive breastfeeding until the sixth month of life and the prevention of pacifier use among infants. Further studies in hospitals not accredited by the CFHI should be conducted in the city of Campina Grande (Paraíba, Brazil) in order to clarify the impact of this strategy on the prevention of early weaning.

\section{Conclusions}

Based on the findings of the present study, pacifier use was associated with early weaning in the analyzed population, even when the mothers were advised to avoid introducing a pacifier.

\section{Acknowlegments}

Contributions of authors: R.V. SOUSA e M.S.P. SILVA performed data collection and analysis; J.M.S.FERREIRA e V. MARTINS performed data analysis and wording; R.D.A.U. LINS performed data analysis; A.F. GRANVILLEGARCIA, V.A. MENEZES, A.C.B. OLIVEIRA and S.M. PAIVA performed guidance and final editing.

\section{References}

1. Volpini CCA, Moura EC. Determinantes do desmame precoce no distrito noroeste de campinas. Rev Nutr 2005; 18:311-9.

2. OPAS/OMS. Amamentação, 2003. Disponível em: <http://www.opas.org.br/sistema/ fotos/amamentar.pdf>. Acesso em: 21 jun. 2010.

3. Neiva FCB, Cattoni DM, Ramos JLA, Issler H. Desmame precoce: Implicações para o desenvolvimento motor-oral. J Pediatr 2003;79:7-12.

4. Granville-Garcia AF, Menezes $V$, Lima N, Zirmeman M. Importância da amamentação: uma visão odontológica. Arq Odontol 2002;38:191-9.

5. Alves AML, Silva EHAA, Oliveira AC. Desmame precoce em prematuros participantes do método mãe canguru. Rev Soc Bras Fonoaudiol 2007;12:23-8.

6. Araújo OD, Cunha AL, Lustosa LR, Nery IS, Mendonça RCM, Campelo SMA. Aleitamento materno: fatores que levam ao desmame. Rev Bras Enferm 2008;61:488-92.

7. Silveira RP. Prevalência de desmame precoce em um distrito sanitário da Amazônia Ocidental. Rev Bras Med Fam e Com. 2006;2:5-14.

8. Uchimura NS, Gomes AC, Uchimura TT, Yamamoto AE, Miyazato P, Rocha SF. Estudo dos fatores de risco para desmame precoce. Acta Sci 2001 ;23:713-8.

9. Menezes VA, Granville-Garcia AF, Silva PM, Silva RB, Falcão AL, Cavalcanti AL. Fatores associados ao desmame precoce no município de São Jose dos Bezerros/PE. UFES Rev Odontol 2008; 10:14-21.

10. Araújo CMT, Silva GAP, Coutinho SB. Aleitamento materno e uso de chupeta: repercussões na alimentação e no desenvolvimento sensório motor oral. Rev Paul Pediatria 2007; 25:59-65.

11. Perez-Escamilla R, Lutter C, Segall AM, Rivera A, Treviño-Siller S, Sanghvi T. Exclusive Breast-Feeding Duration Is Associated with Attitudinal, Socioeconomic and Biocultural Determinants in Three Latin American Countries 1 -4. J Nutr 1995;125:2972-84.

12. Ministério da Saúde, Secretaria de políticas de saúde, Área de saúde da criança Prevalência de aleitamento materno nas capitais brasileiras e no Distrito Federal. Brasília: Ministério da Saúde; 2001.

13. Parizoto GM, Parada CMGL, Venâncio SI, Carvalhaes MABL. Tendência e determinantes do aleitamento materno exclusivo em menores de 6 meses. J Pediatr 2009;85:201-8.

14. UNICEF/OMS. Iniciativa hospital amigo da criança, 2009. Disponível em:<http://bvsms. saude.gov.br/bvs/publicacoes/iniciativa hospital amigo crianca modulo2.pdf $>$. Acesso em: 29 jun. 2010.

15. Frankfort-Nachmias C, Nachmias D. Research Methods in the Social Sciencens. 4. ed. London: Edward Arnald; 1992. 200p.

16. Venancio SI, Escuder MML, Kitoko P, Rea MF, Monteiro CA. Frequência e determinantes do aleitamento materno em municípios do estado de São Paulo. Rev Saúde Pública 2002;36:313-8.

17. Faleiros JJ, Kalil G, Casarin DP, Laque Jr PA, Santos IS. Avaliação do impacto de um programa de puericultura na promoção da amamentação exclusiva. Cad Saúde Pública 2005;21:482-89.

18. Kummer SC, Giugliani ERJ, Susin LO, Folletto JL, Lermen NR, Wu VYJ, et al. Evolução do padrão de aleitamento materno. Rev Saúde Pública 2000;34:143-8.

19. Vieira GO, Almeida JAG, Silva LR, Cabral VA, Netto, PVS. Fatores associados ao aleitamento materno e desmame em Feira de Santana, Bahia. Rev Bras Saúde Matern Infant 2004;2:143-50.

20. Avery M, Duckett L, Dodgson J, Savik K, Henly SJ. Factors associated with very early weaning among primiparas intending to breastfeed. Matern Child Health J 1998; 2 : 167-79. 
21. Baptista GH, Andrade AHHKG, Giolo SR. Fatores associados a duração do aleitamento materno em crianças de famílias de baixa renda da região sul da cidade de Curitiba, Paraná, Brasil. Cad Saúde Pública 2009;25:596-604.

22. Hawkins SS, Griffiths LJ, Dezateux C, Law C. The Millennium Cohort Study Health Group. Maternal employment and breast-feeding initiation: findings from the millennium cohort study. Paediatr Perinat Epidemiol 2007;21:242-7.

23. Kramer MS, Barr RG, Dagenais S, Yang H, Jones P, Ciofani L, Jané F. Pacifier Use, Early Weaning, and Cry/Fuss Behavior. JAMA 2001 ;286:322-6.

24. Newman J Breastfeeding problems associated with the early introdution of botles and pacifiers. J Human Lact 1990;6:59-63.

25. Howard CR, Howard FM, Lanphear B, Blieck EA, Eberly S, Lawrence RA. The effects of early pacifier use on breastfeeding duration. Pediatrics 1999;103:1-6. 